\title{
The Development Of A Code Of Ethics: An Online Classroom Approach To Making Connections Between Ethical Foundations And The Challenges Presented By Information Technology
}

\author{
Rochelle Brooks, Viterbo University, USA
}

\begin{abstract}
In today's organizations, ethical challenges relate to areas like fraud, right to privacy for consumers, social responsibility, and trade restrictions. For Information Technology (IT) specifically, these can translate to considerations on how technology is used to violate people's privacy, how automation leads to job reductions, or how management information and its corresponding systems are used and abused for personal gain. In the last 25 years, we have seen an overwhelming technology infusion affecting business, education, and society. Virtually all areas of our society have been transformed by the usage of technology. The change is important from an ethical perspective in terms of who Information Technology (IT) workers are today and what their tasks are. In the 1980s, IT workers were mainly limited to technical fields, such as programming, data processing, server administration, and phone services. Today, IT workers are integrated into every department of organizations, they function globally, and they have access to a wealth of knowledge and information (Payne \& Landry, 2006). With the power and the skills to access such large amounts of data comes the need for ethical employees. Morality of respect doesn't appear, fully formed, at a particular age. Instead it develops slowly and higher education needs to take a role in this. Higher education, specifically in business schools, needs to take some responsibility in preparing students for the ethical usage of information technology and the underlying information within those systems. In this research investigation, an assignment was provided to students in an online course entitled Ethics and Technology in which they were given the opportunity to develop a code of ethics that focused on key challenge areas in the usage of information technology while at the same time making connections to ethical leaders.
\end{abstract}

Keywords: Adult learning, Code of ethics, Computer ethics, Ethics education, Subsumption ethics

\section{INTRODUCTION}

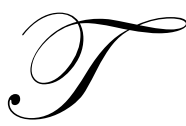

he Computer Professionals for Social Responsibility (CPSR) web site provides us food for thought when they state, "Technology is driving the future, the steering is up to us.... and we need every hand at the wheel" (Computer Professionals for Social Responsibility, 2007). So how do we prepare for taking the wheel as an individual working with Information Technology (IT) or Information Systems (IS)?

A broader view of social responsibility is coming into focus; it is one that incorporates some real Information Technology (IT) flash points. Issues that have long been concerns of corporate technology managers, including security, privacy and intellectual property, are increasingly understood as matters of ethics and good citizenship. This perspective is far from universal. The research of CIO (Chief Information Officer), a leading information technology trade journal, shows that while IT managers are very aware of "the larger effect of 
technology on people's lives," nearly half those surveyed say IT pros are "not very concerned" about it (Cone, 2008).

This more global understanding of technology's powerful role in society is not new. Computer Professionals for Social Responsibility, an organization which deals with related issues, was founded in 1983. Much has been written on technology's impact on the way we live and work, including musings on the moral aspects of a wired society. But the sense that these issues encompass the day-to-day operations of corporate IT appears to be gaining popularity.

According to Donald Amoroso, chair of the computer science and information systems department at Kennesaw State University in Georgia, it is a piece of the maturing of information technology. As the job becomes less about the technology itself and more about the information, the definition of responsible corporate citizenship changes, too. "Social responsibility has to do with being a good person in different parts of the community," Amoroso says. "It determines how you will function and do your job in a societal sense, not just as part of the community you do philanthropy with" (Cone, 2008).

At the 2007 conference of the Information Resources Management Association, Amoroso co-chaired a track entitled "Social Responsibility in the Information Age." Topics included security, privacy, intellectual property, and electronic monitoring of employees, along with more familiar corporate concerns like diversity. Such issues are not just technology problems with regulatory and legal compliance implications; they are ethical concerns that say something important about the people who deal with them daily, and about the corporate culture in which they work. "This is maybe a different frame, a different dimension, to look at these things as social responsibility issues," Amoroso says. "A lot of these things are ethical issues first - everything from developing codes of conduct for the use and management of information, to confidentiality with partners in e-business" (Cone, 2008).

Problems like data security and privacy are more than technical questions or issues of potential liability; they demand that people handling sensitive information have a sense of doing the right thing. Amoroso states that, "This is about more than the letter of the law; it involves the spirit of the law" (Cone, 2008).

\section{WHY COMPUTER ETHICS?}

According to Johnson (2009), the "why computer ethics?" question is complex. Part of the puzzle has to do with technology in general, because technologies other than computers have also posed complex ethical issues. Johnson (2009) asks us to consider all of the concern that was expressed about the power of the atomic bomb during World War II. There were many questions to ask: Should such a powerful tool be created and ultimately used? What would this mean to world politics? Consider more recent issues such as the public debates about nanotechnology, cloning, stem cell research, and mind-alternating pharmacology. All of these technologies have stirred fear and apprehension as well as fascination and hope. In each case, the literature expressing concern about the new technology has suggested that humanity has acquired a new capacity that takes us into new ethical territory. What this means for computer ethics is that part of the "why computer ethics?" question has to do with the technology in general. Why do new technologies present ethical issues and what is the connection between ethics and technology?

Johnson (2009) also addresses that the other part of the "why computer ethics?" puzzle is specific to IT and whether there is something unique about this set of technologies that gives rise to a distinctive kind of ethical issue. It generally appears that information technology seems to create more ethical challenges than other kinds of technology such as electricity, automobiles, and bridges.

This leads us to the need for reflection that is presented by information technology. Johnson (2009) feels that the "why computer ethics?" question is what can be characterized as a "metaquestion"--a question about how we are asking our questions. The question calls us to step back from the engagement with the issues to reflect on our engagement. 
An area of focus in information technology is subsumption ethics. Subsumption ethics is the process by which decisions become incorporated into the operation of information technology (IT) systems, and subsequently forgotten. IT systems, by nature, repeat operations over and over. If those operations have unethical impacts, the system will continue to execute them regardless of the impacts. Unlike a human operator, there is no point in the cycle where the machine pauses to ask, "Should I do this?" Subsumption, according to Gleason (1999), in general is the process of building larger components from smaller ones. In this sense, a cell subsumes DNA function, American common law subsumes judicial decisions, and a hairdryer subsumes an electric motor. Subsumption in computers is different because there is so much more of it going on than in simple machines (Gleason, 1999).

In computer systems, small components are developed and tested, and once they are working reliably they are subsumed into larger systems. This is the enabling technique of object oriented programming. The larger systems, in turn, are subsumed into still larger systems. Once components, subsystems, and applications are operating, the subsumed process becomes invisible and unavailable to the user, what Moor (1985) calls the "invisibility factor." James Moor is a primary figure in the growing area of computer ethics. His award winning article, "What is Computer Ethics?" is widely reprinted and regarded as a milestone in the study of computer ethics.

Fundamentally, computer-based systems are little more than enablers for information misbehavior. Many of the newer information technologies enable persons to perform unethical or illegal actions more rapidly than in the past, to perform more clever or deceitful actions that might not have been manageable before the technology emerged, and to perform illicit activities without being easily identified. With computers and networks being so ubiquitous and accessible in today's workplace, the numbers of people who might knowingly perform an inappropriate act with them has grown rapidly (Brooks, 2008).

According to Moor (1985), a typical problem in computer ethics arises because there is what he refers to as a policy vacuum about how computer technology should be used. It is evident in today's technology driven environment that computers provide us with new capabilities which give us new choices for action. In many cases, either no policies for conduct in these situations exist or the policies that do exist are inadequate. A goal of computer ethics is to determine what we should do in these cases. Computer ethics includes "consideration of both personal and social policies for the ethical use of computer technology" (Moor, 1985).

A survey of the literature in the field of computer ethics suggests that the consensus to the question of "why computer ethics?" lies in the seminal work published by Moor in 1985. According to Moor (1985) computers create new possibilities and new opportunities for human action. We need to be open to the new opportunities for unbiased knowledge. According to Plato, "The highest object of knowledge is the essential nature of Good, from which everything is good and right derives its value for us."

Some of the ancient philosophers such as Plato, Aristotle, and Socrates focused on discussing ethics, as well as the ideals of a life that is good. These ethical leaders demonstrated a profound understanding of the necessary elements needed for a society to be one that is healthy and one that endures. According to what is presented as ancient wisdom, the search for the ultimate truth will be an unending process. The responsible investigator keeps uncovering layers of the truth in light of the constant entry of new evidence. Now we apply these concepts to our contemporary world of information technology. So, it appears that the infusion of emerging technologies creates challenges due to the ethical issues presented. But the challenges do not stop there. The current trends suggest that the stages one goes through to build the foundation of good morals readily accepted into societal norms are in jeopardy.

\section{THE ETHICS OF AMERICAN YOUTH}

There is no question that starting young is the best time to address teaching good morals and ethics. The problems start before students complete their college education and a recent survey by the Josephson Institute (2009) shows that the problems are only getting worse. The mission of the Josephson Institute is "to improve the ethical quality of society by changing personal and organizational decision making and behavior" (Josephson Institute, 2009). 
According to their website, the Josephson Institute has conducted a national survey of the ethics of American youth every two years since 1992 where data is gathered through a national sample of public and private high schools. Josephson Institute's 2008 Report Card on the Ethics of American Youth is based on a survey of almost 30,000 students in high schools across the U.S. It is noted that the results paint a troubling picture of our future politicians and parents, cops and corporate executives, and journalists and generals (Josephson Institute, 2009). That troubling picture carries forward to the people who use Information Technology. That is concerning because the result of unethical usage of this technology can have serious effects.

The results of the 2008 survey are summarized into three main areas (stealing, lying, and cheating) and compared to the 2006 survey results as presented on the organization's web site (Josephson Institute, 2009):

\section{Stealing}

In bad news for business, more than one in three boys ( 35 percent) and one-fourth of the girls (26 percent) - a total of 30 percent overall - admitted stealing from a store within the past year. In 2006 the overall theft rate was 28 percent ( 32 percent males, 23 percent females).

\section{Lying}

More than two of five (42 percent) said that they sometimes lie to save money. Again, the male-female difference was significant: 49 percent of the males, 36 percent of the females. In 2006, 39 percent said they lied to save money (47 percent males, 31 percent females).

\section{Cheating}

Cheating in school continues to be rampant and it's getting worse. A substantial majority (64 percent) cheated on a test during the past year ( 38 percent did so two or more times), up from 60 percent and 35 percent, respectively, in 2006. There were no gender differences on the issue of cheating on exams.

As bad as these numbers are, it appears they understate the level of dishonesty exhibited by America's youth. More than one in four (26 percent) confessed they lied on at least one or two questions on the survey. Experts agree that dishonesty on surveys usually is an attempt to conceal misconduct.

Despite high levels of dishonesty, respondents have a high self-image when it comes to ethics. A whopping 93 percent said they were satisfied with their personal ethics and character and 77 percent said that when it comes to doing what is right, "I am better than most people I know."

The Josephson Institute's biennial survey findings on the ethics of American youth have shown widespread lying and cheating among teenagers. The new report suggests that unethical teenagers become unethical adults (Josephson Institute, 2009). We can assume that the results of the survey also paint a concerning picture of our future users and administrators of information technology in our organizations. The trade journals confirm that there is a problem.

\section{THE "DARK SECRETS, UGLY TRUTHS--AND LITTLE GUIDANCE" IN IT ETHICS}

An example presented by Harbert (2007) gives us a reason to take notice. What Bryan found on an executive's computer several years ago still weighs heavily on his mind. He is extremely troubled by the male employee he discovered using a corporate computer to view pornography of Asian women and of children. This male employee was later promoted and moved to China to run a manufacturing plant. "To this day, I regret not taking that stuff to the FBI," says Bryan. This happened when Bryan was IT director at the U.S. division of a \$500 million multinational corporation based in Germany (Harbert, 2007).

This company had an Internet usage policy which Bryan had assisted in developing with input from senior management. This policy - like most other corporate policies - prohibited the use of a company computer to access 
pornographic or adult-content Web sites. One of Bryan's duties was to monitor employee Web surfing using products from SurfControl PLC and report any violations to management. When the tools turned up dozens of pornographic Web sites visited by the exec's computer, Bryan followed the policy and went to his manager with copies of the Web logs (Harbert, 2007).

Bryan's case is a good example of the ethical dilemmas that IT workers may encounter on the job. IT employees have privileged access to digital information, both personal and professional, throughout the company, and they have the technical prowess to manipulate information. That gives them both the power and responsibility to monitor and report employees who break company rules. IT professionals may also uncover evidence that a coworker is possibly embezzling funds, or they could be tempted to peek at private salary information or personal emails. But there's little guidance on what to do in these uncomfortable situations (Harbert, 2007).

The temptation for curiosity is human nature, but at what point does it infringe upon unethical behavior? This needs to be discussed in our college classrooms. If students are being taught how to use the technology, shouldn't they also be presented with the ethical issues which the technology brings to the organizations in which they will be employed? Once employed, continued efforts of promoting awareness of ethical issues needs to be lead by management in our technology-driven organizations.

The literature presented in the trade journals in the field of information technologies makes note of several examples of "dark secrets, ugly truths--and little guidance" in reference to ethics in Information Technology. According to security company Cyber-Ark Software, Ltd., a survey conducted during the spring of 2007 found that one-third (33 percent) of 200 IT employees who responded admitted to using their administrative passwords to snoop through organizational computer systems and peek at confidential information including salary. IT professionals admitted to snooping through confidential company information such as salary, personal e-mails, and human resources information (Harbert, 2007).

Another survey done twelve months after the Cyber-Ark survey discovered that 33 percent of IT staff used their administration rights to snoop around networks to gain access to privileged, corporate information such as HR records, layoff lists, and customer databases. The results have not improved. Unfortunately, a repeat of the survey has discovered that the snooping situation has escalated. Despite increased media awareness on the subject, the third annual survey reveals that 35 percent of IT workers now admit to accessing corporate information without authorization, while 74 percent of the respondents stated that they could circumvent the controls currently in place to prevent access to confidential organizational information (Cyber-Ark, 2009).

A poll of more than 16,000 U.S. IT practitioners conducted in June 2007 by the Ponemon Institute returned these equally disturbing findings:

- $\quad 62 \%$ of IT employees polled said they had accessed another person's computer without permission.

- $\quad 50 \%$ said they had read confidential or sensitive information without a legitimate reason.

- $\quad 42 \%$ said they had knowingly violated their company's privacy, security, or IT policies.

- $32 \%$ of the respondents were at or above the manager level, and the average experience level was 8.4 years (Harbert, 2007).

The Ponemon Institute is dedicated to independent research and education that advances responsible information and privacy management practices in business and government. The Ponemon Institute's services include industry-wide studies, proprietary (commissioned) tracking studies, training and consultancies on trends in privacy and data protection. The Ponemon Institute is the parent organization of the Responsible Information Management (RIM) Council. The RIM Council obtains its name from the practice of Responsible Information Management, an ethics-based framework and long-term strategy for managing personal and sensitive employee, customer and business information (The Ponemon Institute, 2009).

According to the Society for Information Management (SIM), "Ethics and Morals" was listed as the top skill in the list of top 15 skills that their members are seeking in entry level employees. This was followed by "Critical Thinking and Problem Solving" as number two on the list (Lundquist, 2008). The online survey conducted 
in June of 2008 by SIM asked 231 IT leaders to name the top workplace skills they seek when hiring new employees. The results of this survey were released at its SIMposium 2008 in the fall of 2008. According to the results of the survey, these IT leaders overwhelmingly cited ethics and morals as the traits they most desire both among entry-level and mid-level IT workers. SIM is an association of senior IT executives, prominent academicians, consultants, and other IT thought leaders which has headquarters in Chicago (Hoffman \& Harbert, 2008). The results clearly indicate that character is important for workers in the Information Technology industry.

Many Information Technology executives are concerned about all of the stories that they have heard of IT staffers doing "unethical things," such as circumventing security systems, according to Jerry Luftman, a professor at Stevens Institute of Technology in Hoboken, N.J., and SIM's vice president of academic affairs. Luftman, who also is executive director of the information systems graduate programs at Stevens, added that cheating scandals have disturbed some U.S. colleges. "It's hot on everyone's minds," Luftman said. "This whole issue of ethics and morals is becoming paramount to IT executives" (Hoffman \& Harbert, 2008). The problems with the dark secrets and ugly truths regarding ethics in Information Technology (Harbert, 2007) are being recognized and attempts are being made to correct the problems.

While some companies have policies, they tend to vary widely depending on the organization's size, culture, and management. It also varies depending on whether the organization is public or private. The fact remains that the most detailed corporate ethics policy cannot cover every situation that will develop. Additionally it will not be well known in all areas of the company (Hoffman \& Harbert, 2008).

In regards to the policies that do exist, some focus on areas where the organization may have had past issues or some will emphasize the biggest concern of the organization. As an example, when John Reece was at the IRS, he felt that the biggest emphasis was on the protection of confidentiality of taxpayer information (Harbert, 2007). At other government agencies, such as the U.S. Department of Defense, policies usually emphasize procurement rules, according to Stephen Northcutt, president of the SANS Technology Institute and author of IT Ethics Handbook: Right and Wrong for IT Professionals. "It's quite often the case that if [a transgression] hasn't happened yet, no one thinks of it or wants to focus on it," says Leslie Ann Skillen, a partner at the law firm of Getnick \& Getnick. Skillen is an expert on fraud and corruption in business and government (Hoffman \& Harbert, 2008). To add to the challenges, an organization that employs highly creative or highly skilled workers might be more lenient in some areas (Hoffman \& Harbert, 2008). Many adults taking ethics courses share this concern.

When Northcutt worked in IT security at the Naval Surface Warfare Center in Virginia, it was an atmosphere of highly sought-after Ph.D.s. "I was told pretty clearly that if I made a whole lot of Ph.D.s very unhappy so that they left, the organization wouldn't need me anymore," says Northcutt. As can be expected, that was not written in any policy manual, so Northcutt had to read between the lines. "The way I interpreted it was: child pornography, turn that in," he says. "But if the leading mathematician wants to download some pictures of naked girls, they didn't want to hear from me." Northcutt reports that he did find child porn on two occasions and that both events led to prosecution. In regards to the naked photos that he encountered, Northcutt notified his superiors that they might be a legal liability. To make his case, Northcutt cited a Supreme Court decision that found similar pictures at a military installation indicated a pervasive atmosphere of sexual harassment. Only then did they change their policy. "Once they saw that law was involved, they were more willing to change culture and policy," according to Northcutt (Hoffman \& Harbert, 2008).

This is the challenge. When policies are not clear, ethical decisions are left to the personal judgment of the IT employees, but that judgment varies dramatically from person to person. For example, where Northcutt pushed to get the policy changed, another manager might have accepted the status quo. According to observers, often the decision depends on the type, frequency and severity of the incident, as well as the possible consequences of action or inaction. It appears that even people who insist on a high personal standard of ethics for one type of behavior may bend the rules in other areas, for various reasons (Hoffman \& Harbert, 2008).

For example, Gary, a director of technology at a nonprofit organization in the Midwest, refused when his assistant CEO wanted to use a mailing list that a new employee had stolen from her former employer. Not only was it illegal, but he also stated that "it's morally reprehensible and I wasn't about to participate in anything that would 
damage the reputation of the organization." However, when his boss installed unlicensed software on PCs for a short time, Gary acknowledges he was willing to look the other way. He informed his boss that it was not ethical and he refused to do it himself. Yet, he didn't stop it: "The question is, how much was it really going to hurt anybody? We were still going to have 99.5 percent compliant software. I was okay with that." He says he uninstalled it, with his boss's approval, as soon as he could - about a week later (Hoffman \& Harbert, 2008).

As the examples show, the lines are blurry in terms of ethical versus unethical behavior. We have a challenge in front of us. How do we successfully engage students in learning activities so that they can be prepared for these challenges?

\section{ETHICS EDUCATION IN INFORMATION TECHNOLOGY: CAN WE MAKE A DIFFERENCE?}

According to Vitolo and Brinkman (2007), teaching ethics is not about teaching right versus wrong; teaching ethics is about teaching informed discernment, conscientious decision making, and balanced living. This brings forth the question: Should teaching these behaviors be the domain of higher education?

For many years and in many institutions--unfortunately, even today--the teaching of ethics has not been embraced as part of the charge of higher education. However, as society has had to assimilate technology and as society and today's organizations have had to face the repercussions of unethical and illegal behaviors, one questions the ethical training of the professionals making the decisions. Since these professionals are the products of higher education, many institutions and accreditation boards are requiring their students to have exposure to ethical philosophy (Vitolo \& Brinkman, 2007).

According to the literature, it has been noted that students in the technical fields may not benefit from a purely philosophical course presentation of ethics. As validated in a recent study, introducing the ethical dilemmas associated with real-life decisions about information technology can be very influential and eye-opening to the student. While institutions have always been teaching students how to debug technology problems, institutions also need to teach students how to debug ethical decisions--to become aware that ethical decisions are also technology problems to be analyzed, understood, and appropriately resolved (Vitolo \& Brinkman, 2007).

According to Quinn (2006), many computer science programs created their own computer ethics course for a pragmatic reason: During a previous accreditation visit they had a difficult time demonstrating they had met Standard IV-17, which put the program's accreditation at risk. In ABET's Computing Accreditation Commission, in order to receive accreditation, a program must meet various intents. Standard IV-17 states, "There must be sufficient coverage of social and ethical implications of computing to give students an understanding of a broad range of issues in this area." ABET is the accreditation board for engineering and technology. A generic ethics course taught within a philosophy department is unlikely to spend enough time on information-technology-specific case studies. When ethics is taught across the curriculum, it is more difficult to guarantee that instructors will actually create learning activities that will be assessed properly. Even if instructors do create these assessment opportunities, it can still be difficult for the department to gather the evidence. For these reasons, designing and requiring a separate computer ethics course makes it more feasible for an academic department to demonstrate that its undergraduate program satisfied Standard IV-17 based on the investigations of Quinn (2006).

The Association for Computing Machinery (ACM) has Special Interest Groups in various areas. One of those is the Special Interest Group for Information Technology Education (SIGITE). SIGITE's mission is to provide a forum for the interaction of practitioners, educators, and others in the field of Information Technology Education in order to exchange ideas and engage in activities that advance the knowledge of its members, the curriculum and teaching on Information Technology Curriculum, and the development and transfer of innovative concepts and applications in technology and pedagogy. SIGITE currently has a focused effort on the development of a model curriculum and guidelines for accreditation (SIGITE, 2009).

According to SIGITE (2009), in addition to technical skills, an Information Technology professional must understand the social and professional context of information technology and computing, and adhere to ethical and legal aspects of computing. Many university curriculums are designed based on the guidelines presented by 
SIGITE. The guidebook for IT curriculum development entitled Information Technology 2008: Curriculum Guidelines for Undergraduate Degree Programs in Information Technology includes the word "ethics" 27 times in the document (SIGITE, 2008). This could be an indication of the importance of ethics in information technology education.

What do students think about the subject matter? What are the hot topics? What is the foundation for teaching such a course? How to we prepare today's students for the ethical challenges presented by technology in the workplace? What type of impact does this type of course have on the people who complete the course? These are all questions that certainly merit further investigation.

\section{UNDERSTANDING ADULT LEARNING THEORIES IN TEACHING IT ETHICS}

Zemke and Zemke (1995) report that adults seek out learning experiences only when they see a need for a new or different skill or knowledge. They are often motivated to learn by their desire to improve their ability to cope with life-changing events or to promote personal growth. To facilitate adult learning, experts say that the learning experience should be problem-centered, include preprogram assessment, promote information integration, and involve realistic exercises and cases. In addition, the curriculum program should take into account learningstyle differences, and should consider the issues of feedback and recognition as well as the desire of adults for continued growth. An adult learning program will also be effective if it is conducted in a safe and comfortable environment, offers facilitation rather than lecture, and promotes understanding and retention.

Zemke and Zemke (1995) conclude that helping adults acquire new skills and knowledge is an exhilarating, irritating, challenging, and frustrating way to make a living. It takes patience, forbearance, flexibility, humor, and a strong belief that what you are doing matters. If we keep trying and prodding and testing and trying again, we might turn this art form into a science of sorts.

In today's high performance organizations workers must be prepared for continuous on-the-job growth and development. Given the increased age, variety of experiences, and growing world of technology, it is critical that adult education practices develop past traditional models of education where the instructor serves as the transmitter of knowledge and the students remain the inactive recipient of that knowledge. In adult education, methodology that takes advantage of the worker's previous experiences, connects practices and concepts, and encourages reflection and transfer of knowledge from one situation or application to another are critical to the learning process.

\section{RESEARCH QUESTION}

Given the results from the Josephson Institute study of high school students and the "ugly truths" reported in the information technology trade journals, how does higher education prepare students to ethically use and manage information technology?

It is evident that students need guidance in making ethical decisions that are unique in today's technologydriven world. It appears that the more savvy the population becomes in developing and using technology, the greater the risk that it will be used in a detrimental way against individuals, organizations, or society in general. We seem to be constantly struggling with new concepts that simultaneously present new opportunities along with new problems, or rushing to promote new legislation to counter some new threat, or redefining societal norms for our technologically-dependent world. Now is the time for philosophy (the study of ethics) and technology to meet. Managing computers ethically - that is, acting ethically and assisting others to do likewise - is no easy task for either an individual or an organization.

\section{UNDERSTANDING THE SOURCE OF THE CHALLENGES}

Some feel that there has been a shift in focus from the "we" generation to the "me" generation. If this is true, there will need to be a major paradigm shift before we can see ethics deeply engrained in every facet of our lives. 
The technology itself makes moral and ethical decision making challenging. In some cases, the anonymity provided by information technology greatly reduces the likelihood of punishment or any sort of consequences, which is an important part of early moral development. How would we choose to act if we became invisible; would we do whatever we want if we knew that we could not be detected, or would we still hold unfaltering to our own morality (Brooks, 2008)?

For more than a decade, the necessity of undertaking ethical issues relating to Information Technology (IT) development have been expressed and seriously debated by both philosophers and many concerned IT professionals. Along with significant benefits of the Information Age come significant ethical dilemmas. Every day the news media reports of issues surrounding intellectual property, data collection, improper use of technology and social implications, such as job displacement and unequal access across socio-economic levels (Brooks, 2008).

Are the IT professionals on the front lines of decision-making prepared to respond to these challenges? Are they even aware of them? As the trade journals and the surveys show, awareness is not sufficient. We have been so busy racing to keep up with rapid computing advances that we have not taken the time to address the larger societal implications. The ethical development of information systems is but one of those sensitive scenarios associated with computer technology that has a tremendous impact on individuals and social life. The significance of these issues of concern cannot be overstated. However, since computer ethics is meant to be everybody's responsibility, the result can often be interpreted as nobody's responsibility. Therefore, an effective while still practical moral framework needs to be recognized in order to put computer ethics on a sound foundation for further exploration (Brooks, 2008).

When ethical problems or issues related with information technology have been put forward and recognized, the most needed work is to find an effective way out of such dilemmas. Based on this study and the discussion of students in various ethics courses, among popular solutions are those that introduce ethical codes of conduct. It is also critical to stress that the relevant parties give IS development procedures and products a secondary review. Lastly, there needs to be a focus on the importance of ethical training for practicing or potential IT professionals.

It is time to become sensitized to all the aspects of information technology that involve ethical components. At times in the process of system analysis and design, someone needs to stop and say, "There is an ethical dilemma here and I need to analyze it before I can move forward."

According to Harbert (2007), in theory, ethical behavior is governed by laws, corporate policy, professional ethics and personal judgment. But as IT pros experience in their jobs, this can be one of the most overwhelming challenges in their careers. Perhaps it would ease Bryan's conscience to know that he did just what labor attorney Linn Hynds would have advised for this case. "Let the company handle it," she says. She recommends to make sure you report violations to the correct individual in your company and to provide the evidence. She feels that you then need to leave it to the people who are responsible for making the decisions. Ideally, corporate policy should take over where the law stops in governing workplace ethics to clear up gray areas and remove personal judgments from the equation as much as possible.

Another example shows the need for continued concern. When Tim, a systems administrator, discovered an unencrypted spreadsheet of salary information on a manager's PC, he copied it. He states that he didn't share it or use it to any advantage. His reason for taking the file was simply to prove he could. Tim's actions point to a disturbing trend: IT workers justifying their "ethically questionable behavior" (Harbert, 2007). The examples provided in the trade journals continue to validate the survey results. Something needs to be done to reduce the unethical activity where information technology is the tool.

\section{THE NEED FOR ETHICS EDUCATION}

A study published by Awasthi (2008) showed that individuals who had taken an ethics course were "more included to judge unethical decisions managerially bad than others." Awasthi (2008) showed in this study that depending on how a situation was framed, ethically or managerially, the outcome of the decision-making would be completely different. This indicates that mandating an ethics course for managers would benefit not only the 
managers but the company morale as a whole also. It is also important to incorporate the study of ethics in university curriculums.

Additionally, given the ubiquitous role of the IT professional, it is unfortunate that a comprehensive code of ethics does not yet exist. IT professionals, like those in all walks of life, should behave ethically (Payne \& Landry, 2006). According to Frank Abagnale, former con man and now a 32 year veteran with the FBI, "The more technology there is in the world, the more you have to instill character and ethics." In his interview with Tennant (2007, p. 4), editor in chief of Computerworld, Abagnale states the following:

There are about four reasons why we have crime to begin with. One of them is, of course, that we live in an extremely unethical society. We live in a society that doesn't teach ethics at home, a society that doesn't teach ethics in school because the teacher would be accused of teaching morality. We live in a society where you can't find a four-year college course on ethics...... So today you have a lot of young people who have no character, no ethics, and they find no problem in defrauding somebody or stealing from somebody or cheating somebody. Until we change that, crime is just going to get easier, faster, more global, harder to detect.

Tannant (2007) asked Abagnale how we can bring about that change. His answer was simply, "You need to bring character and ethics back into schools. You need to bring it back into colleges and universities as part of a curriculum." According to Tennant (2007, p. 4) in regards to Frank Abagnale, "It turns out the former con man is the real ethics guru."

\section{THE IMPORTANCE OF A CODE OF ETHICS}

IT professionals are obligated to the advancement of the ethical and responsible use of all information technology resources. Developing and maintaining a code of ethics specific to the IT profession is essential to the creation of a culture that fosters trust and a commitment to responsibility, honesty, corporate integrity, and personal integrity while abstaining from conflicts of interest and perceived improprieties. Organizations must not tolerate illegal, dishonest, improper or irresponsible use of privileged access of information. Establishing a code of ethics does not, in and of itself, guarantee ethical behavior. That will only be achieved by applying the principles of the code of ethics to the execution of daily business.

\section{A LEARNING ACTIVITY}

In this research investigation, an assignment was provided to students in an online summer course entitled Ethics and Technology bachelor's degree program within a business program for a school of adult learning at Viterbo University in La Crosse, Wisconsin, to give the opportunity for them to develop a code of ethics that focused on key challenge areas in the usage of information technology. These issues included Computer/Internet Crime, Privacy, Freedom of Expression, Intellectual Property, Software Development, Employer/Employee Issues, and IT and Quality of Life. The enrollment consisted of eight students and seven of them provided feedback on the experience. This group served as a focus group for this research study. The following instructions were provided to the students:

Each of you will be assigned four topic areas in which you will develop code statements and supporting rationale. You will use precepts and principles from ethical philosophers (and any other person you feel is an ethical leader) to justify each aspect of your code. You will cite some meaningful quotes or concepts where you feel that you can make a connection to your code statement and then explain that connection.

As a way to make reflections, students were asked to support their code statements with rationale using concepts from who they would consider "ethical thinkers" or "ethical leaders." The code statements were very pertinent to the current times and many of these students pulled in the work of ethical leaders from history to make their case.

The methodology utilized in this study includes content analysis of the assignment's final outcomes in conjunction with the use of this focus group to gain perspectives of the activity and its value in the workplace and in 
life in general. To acquire additional feedback from the focus group, at the completion of the course, the following questions were asked of the group of students:

1. What is the benefit of taking a course dealing specifically with ethical issues presented by information technology?

2. What benefit did you receive from doing the Code of Ethics project in this course where you connected philosophy and connections to ethical leaders to the current IT world?

3. How can a Code of Ethics development activity like this be used in the workplace for the benefit of employees and the organization as a whole?

4. What suggestions can you provide to reduce unethical activity that is connected to Information Technology in the workplace? What is the role of education and training in making this possible?

Summary comments provided as responses to these questions and actual project work results have been compiled for purposes of this study. The findings show an appreciation by adult learners to make connections between philosophy and information technology.

\section{FINDINGS}

The feedback of the focus group was compiled into a 60 page document. In this course in identifying ethical leaders, adult learners cite predictable ethical leaders such as Plato, Albert Einstein, Confucius, Aristotle, and Socrates. Two presidents were also noted: Theodore Roosevelt and Thomas Jefferson.

Many other leaders were mentioned by the students and the feedback from the students was very positive. The connections made between the code statements and the ethical leaders were inspiring. Students thought it was interesting and a great opportunity for reflection to look at the philosophies of Plato and Aristotle and others for the purpose of making connections. Relating the foundations of ethical leaders from past years to show connections to today's challenges with information technology was found to provide a "common sense approach to IT and ethics."

One student provided this input which focuses on responsibility:

There are different approaches to ethics and defining ethics [that] can be controversial in itself. Today, many ethical issues arise from the benefits of utilizing new technology. When ethical values and principles conflict, where do we recognize the difference(s), integrity, respect, costs, and benefits? To make a balanced decision to the benefit of all, all users of IT in whatever industry associated with, need to have a major responsibility in communicating how the new tools of technologies are to be utilized and implemented in their specific industries and for what purpose.

Students felt that the Code of Ethics project was important because it allowed for personal reflection of core values and the reminder of how important it is to act ethically when working with technology and the personal information that is gathered as a result of that technology.

Another student summarized the importance of the course in the following way:

I think taking a course in today's world dealing with ethics and technology is very important! In the world of today we have the technology to do many things that wouldn't have been dreamed of 50 years ago. It is important to discuss issues in a world where we can clone living creatures and have the power to manipulate nature at the genetic and atomic levels. In a sense we, due to technological development, have more power than ever to change the world around us and with this comes an increased responsibility.

In this course, reflection is validated as an appreciated learning tool. In adult education, using the student's previous experiences, connecting practices and concepts, and encouraging reflection and transfer of knowledge from one situation or application to another are critical to the learning process. 


\section{CONCLUSION}

Computer experts collectively and proactively can shape the culture of computing (Johnson, 2009). It is not a task to be taken lightly. This means engaging in an assortment of activities that instill values and attitudes in those who are studying to be experts and in those who already practice in the field. Ethics training does not have closure because technology is a moving target. Progress has to be made to rectify the problems which lead to the ComputerWorld lead story in October 2007: Ethics in IT: Dark secrets, ugly truths--and little guidance. It is time to take GUIDANCE very seriously and we can do that with education. We can provide the tools to be effective in this enormous challenge.

The learning activity in the online classroom based on the development of a code of ethics with supporting rationale connecting to ethical foundations was effective based on the feedback of the focus group. Key feedback centered on the concept of a common sense approach to IT and ethics. The appreciation for reflection on morals and values was also expressed. One learner articulated that this was an important exercise because of the opportunity to think about what is important for the individual. The mental connections created during this project as expressed by one learner made an impact which will help this individual make sound ethical decisions in the future. For one learner, the philosophies of the ethical leaders gave him/her reason to believe that developers today probably did follow their philosophies to continue improving technology.

How does higher education prepare students to ethically use and manage information technology? The findings of this study show that we can effectively start by allowing students to make personal connections between ethical philosophy and the challenges that information technologies present as we develop a code of ethics which can serve as a framework. It is a starting point and appears to be appreciated by the participants in this study.

It is evident that technology is driving the future and that will continue. We need to be proactive in steering based on strong ethics and morals. The belief of the participants of this study is that education in IT ethics can be effective with the appropriate activities leading to making strong connections.

\section{AUTHOR INFORMATION}

Dr. Rochelle Brooks is an associate professor at the Dahl School of Business at Viterbo University. She teaches Management Information Systems, Business Communications, Ethics and Technology, Ethical Leadership and Sustainability, Research Methodology in Business, and is a research coordinator for the $4+1$ MBA program at Viterbo. Dr. Brooks is also a Research Fellow for the D.B. Reinhart Institute for Ethics and Leadership and has research interests in the area of ethical challenges presented by information technology.

\section{REFERENCES}

1. Awasthi, V. (2008). Managerial decision-making on moral issues and the effects of teaching ethics. Journal of Business Ethics, 78, 207-223.

2. Brooks, R. A. (2008). Addressing ethics and technology in business: Preparing today's students for the ethical challenges presented by technology in the workplace. Contemporary Issues in Education Research, 1(2), 23-32.

3. Computer Professionals for Social Responsibility (2007). What is CPSR? Retrieved August 15, 2009, from http://www.cpsr.org/

4. Cone, E. (2008, Sept. 10). Social responsibility: doing the right thing. CIOInsight. Retrieved March 4, 2009 from http://www.cioinsight.com/c/a/Research/Doing-the-Right-Thing/

5. Cyber-Ark (2009, June 10). Global IT security survey finds insider snooping on the rise. Retrieved June 11, 2009, from http://www.cyber-ark.com/news-events/pr_20090610.asp

6. Gleason, D. (1999, March). Subsumption ethics. Computers and Society, 29(1), 29-36.

7. Johnson, D. G. (2009). Computer ethics, 4th ed. Upper Saddle River, NJ: Prentice Hall.

8. Harbert, T. (2007, Otober 29). Ethics in IT: Dark secrets, ugly truths. And little guidance. ComputerWorld, 41(44), 34-36. 
9. Hoffman, T. \& Harbert, T. (2008, November 11). "Ethics and morals" top workplace traits say recruiters. tbusiness.ca. Retrieved March 5, 2009, from http://www.itbusiness.ca/it/client/en/home/News.asp?id=50707\&PageMem=1

10. Josephson Institute (2008, November 30). The Ethics of American Youth - 2008 summary. Retrieved May 20, 2008, from http://charactercounts.org/pdf/reportcard/2008/press-release.pdf

11. Josephson Institute (2009, October 29). Character study reveals predictors of lying and cheating. Retrieved November 24, 2009, from http://josephsoninstitute.org/surveys/index.html

12. Lundquist, E. (2008, December 1). The skills that really matter: Technology prowess isn't necessarily No. 1 on hiring managers' lists. eWeek, 25(35), 46.

13. Moor, J. (1985). What is computer ethics? Metaphilosophy, 16(4), 266-275.

14. Payne, D. \& Landrey, B. J. (2006, November). A uniform code of ethics: Business and IT professional ethics. Communications of the ACM, 49(11), 81-84.

15. Ponemon Institute (2009). Ponemon Institute: Measuring trust in privacy and security. Retrieved November 25, 2009, from http://www.ponemon.org/index.php

16. Quinn, M. J. (2006). On teaching computer ethics within a computer science department. Science and Engineering Ethics, 12 (2), 335-343.

17. SIGITE (2008). Curriculum: Proposed standards for IT curriculum. Retrieved October 2008, from http://www.sigite.org/index.php?option=com content\&view=section\&id=5\&Itemid=26

18. SIGITE (2008, November). Information Technology 2008: Curriculum Guidelines for Undergraduate Degree Programs in Information Technology. Retrieved November 24, 2009, from http://www.acm.org//education/curricula/IT2008\%20Curriculum.pdf

19. Tennant, D. (2007, October 22). The real ethics guru. Computerworld, 41(43), 4.

20. Vitolo, T. M., \& Brinkman, B. J. (2007). Ethics for the graduating class: Issues, needs, and approaches. In Lowry, G. R., \& Turner, R. L. (Eds.), Information systems and technology education: From the university to the workplace (299 - 310). Hershey, PA: IGI Global.

21. Zemke, R., \& Zemke, S. (1995, June). Adult learning: What do we know for sure? Training, 32(6), 31-38. 
NOTES 